\title{
Advanced Turbine Systems Program Conceptual Design and Product Development
}

Quarterly Report

February - April 1995

K. W. Karstensen

July 1995

Work Performed Under Contract No.: DE-AC2 1-93MC30246

For

U.S. Department of Energy

Office of Fossll Energy

Morgantown Energy Technology Center

Morgantown, West Virginia

By

Solar Turbines Incomporated

San Diego, Califomla 


\section{DISCLAIMER}

This report was prepared as an account of work sponsored by an agency of the United States Government. Neither the United States Govemment nor any agency thereof, not any of their employees, makes any warranty, express or implied, or assumes any legal liability or responsibility for the accuracy, completeness, or usefulness of ary information, apparatus, product, or process disclosed, or represents that its use would not infringe privately owned rights. Reference herein to any specific commercial product, process, or service by trade name, trademark, manufacturer, or otherwise does not necessarily constitute or imply its endorsement, recommendation, or favoring by the United States Government or any agency thereof. The views and opinions of authors expressed herein do not necessarily state or reflect those of the United States Government or any agency thereof.

This report has been reproduced directly from the best available copy.

Available to DOE and DOE contractors from the Office of Scientific and Technical Information, 175 Oak Ridge Tumpike, Oak Ridge, TN 3783I; prices available at (615) 576-8401.

Available to the public from the National Technical Information Service, U.S. Department of Commerce, 5285 Port Royal Road, Springfield, VA 22161; phone orders accepted at (703) 487-4650. 


\title{
Advanced Turbine Systems Program Conceptual Design and Product Development
}

\author{
Quarterly Report \\ February - April 1995
}

K. W. Karstensen

Work Performed Under Contract No.: DE-AC21-93MC30246

\author{
For \\ U.S. Department of Energy \\ Office of Fossil Energy \\ Morgantown Energy Technology Center \\ P.O. Box 880 \\ Morgantown, West Virginia 26507-0880
}

By

Solar Turbines Incorporated

9330 Sky Park Court

San Diego, Califomla $\mathbf{9 2 1 3 8}$

July 1995 


\section{CONTENTS}

Paragraph

Page

EXECUTNE SUMMARY

1.0

WORK STATUS

2

1.1 Task 4 - Conversion to Coal . 2

1.2 Task 8 - Design and Test of Crlical Components 2

1.2.1 Subtask 8.1 - Low Pressure Drop Recuperator 2

1.2.2 Subtask 8.2 - Subscale Catalytic Combustion Rig 4

1.2.3 Subtask 8.2 - Autothermal Fuel Reactor (ATR) 10

1.2.4 Sublask B.4 - Dual Property Turbine Disc 11

1.2.5 Subtask 8.5 - Full-Scale, Single Can Catalytic Cornbustor Pig 13

1.2,6 Sublask B.6 - Total Plant Controls 13

1.2 .7 Subtask 8.7 - Recuperator Materials 14

1.2.8 Subtask 8.8 - Low Cost Combustor Materials (Ceramics)

1.2.9 Subtask 6.9 Ađvanced Ceramlc Materlals 14

2.0

PROGRAM SCHEDULE AND BUDGET

14

2,1 Schedule

14

2.2 Budget

14

3.0

FUTURE INVESTIGATIONS

18

APPENDIX 1 - GLOSSARY

10 


\section{FIGURES}

Etgure

Page

1

Steady State Performance Test Rig

3

2

Transient Performance Test Fig

4

3

Flattened Tube Tests and FEM Strain Comparison at

Foom Temperature

7

Catalyst Inlet Velocity Profiles

8

Subscale Catalytic Combustor Test Rig Configured to Flatten Catalyst Inlet Velocity Profile

Catalytic Combustor Resulto

10

7

Tube Reactor for Refomlng Catalyst Screenlng Tests

11

B

Temperature Readouts Monitored by Thermocouples

\section{TAELES}

Teble

Page

1

Transient Performance Data for Core 90 (Gas-Side)

5

Translent Performance Data for Core 91 (Air-Side)

6

Translent Performance Data for Core \#92 (Combined Air/gas)

7

Thin Foll Creep Test Results

Thin Fo:l Creep Testing Summany 


\section{EXECUTIVE SUMMARY}

This Quarterly Technical Progress Report covers the period Febnuary 1, 1995, through Aprit 30, 1995, for Phase Il of the Advanced Turbine Systems (ATS) Program by Solar Tubines Incorporated under DOE contract No. DE-AC21-93MC30246. The objective of Phase Il of the ATS Program Is to provide the conceptual design and producl development plan for an ultra hagh efficiency, environmentally superior and cost competitive industrial gas turbine system to be commercialized by the year 2000. A secondary objective is to begin early development of technologies critical to the success of ATS.

Tasks 1, 2, 3, 5, 6 and 7 of Phase 11 have been completed in prior quarters. Their results have been discussed in the applicable quarterly reports and in their respective topical reports. With the exception of Task 7, final editions of these topical reports have been submitted to the DOE. This quarterly report, then, addresses only Task 4 and the nine subtasks included ta Task 8 , "Design and Test of Critical Components." These nine subtasks address six ATS technologies as follows:

- Catalytic Combustion - Subtasks 8.2 and 8.5

- Recuperator - Subtasks 8.1 and 8.7

- Autothermal Fuel Reformer - Subtask 8.3

- High Temperature Turoine Disc - Subtask 8.4

- $\quad$ Advanced Control System (MMi) - Subtask 8.6

- Ceramic Materials - Subtasks 8.8 and 8.9

Major technological achievements from Task 8 efforts during the quarter are as follows:

- The subscale catalytic combustion rig in Subtask 8.2 is operating consistently at 3 pprnv of NOx over a range of ATS operating conditions.

- The spray cast process used to produce the rim section of the high temperature turbine disc of Subtask 8.4 offers additional and unplanned spin-off opportunities for low cost manufacture of certain gas turbine parts.

On February 23, amendment M004 to the contract was issued to extend the pertod of performance from November 30, 1995 to May 30,1996. The purpose of this no-added-cost extension was to accommodate minor changes in a stubcontractor's statement of work which delayed the start of work. Beginning with the March monthly report, perfomance has been reported against the Labor and Cost Plans included with the Management Plan submitted in connection with amendment M004.

Contract labor and cost status as of April 30, 1995:

Labor: 21,206 hours verșes 22,448 planned.

Total Program Cost": \$2570K versus $\$ 3155 \mathrm{~K}$ planned.

Including Solar's cost share. 
9249 labor hours have been charged to an intemally funded profect directly related to ATS. This represents cost sharing of approximately $\$ 833,000$ in addition to that provided for in the contract.

\subsection{WORK STATUS}

Tasks 1,2,3,5,6 and 7 have been completed and topical reports submitted for each, with the exception of Task 7. The Task 7 topical report is in final review at Sotar and will be submitted early in the next quarter.

\subsection{TASK 4 - CONVERSION TO COAL}

Task 4 of ATS, Phase, II, requires the definition of a system to convert the gas-fueled advariced turine system (CFATS) to a coal-fired advanced turbine system (CFATS). Start of work on this task was delayed until near-înal cycle conditions for the GFATS defined in Task 3 as well as for interim systerns defined in Tasks 5, 6, and 7 became available. Now that the defirition of a GFATS in Task 6 has been completed Task 4 work resumes.

Four approaches to handing both coal- and biomass-derived gaseous fusels have been identifted:

$\begin{array}{ll}\text { - } & \text { Direct Firing } \\ \text { - } & \text { Gressurized Fituidized Bed Combustion (PFBC) } \\ \text { Direct Firing }\end{array}$

Direct coal firing has been the subject of work at Solar under contract to DOE-METC over the past ten years. Experience gained from this work has been applied in evaluating direct coal firing for ATS. PFBC and indirect firing both present major control challenges during engine start-up and load changes due to the large air volumes involved. Gasification appears to be the most practical approach for use with a modified ATS combustion system.

Costing of the infrastructure required for all four systems has been started. It is expected that these analyses will support the choice of gasification as the appropriate CFATS conversion scheme. The work will then conclude with an economic analysis of coal as an alternative fuel to natural gas in Solar's advanced turbine system.

\subsection{TASK \& - DESIGN AND TEST OF CRJTICAL COMPONENTS}

During this quarter, work progressed on all mine of the Task 8 Subtasks as reported in the following discussion.

\subsubsection{Subtask 8.1 + Low Pressure Drop Recuperator}

Subtask 8.i has three objectives:

- To measure performance of the ATS recuperator core over the range of ATS operating conditions.

- To determine the basic heat transfer and flow loss characteristics of the ATS recuperator heat transfer surface. 
- To validate analytical methods employed to predict core creep life.

The first two abjecthes were addressed by testing on steady state and transient recuperator rigs at the Caterpilis Technical Center near Peoria, 11. The thitri involves measurement of creep strain in an Intemally pressurized, flattened tube specimen which simulates the folded fin conflguration of the ATS primary surface recuperator (PSR). This flattened tube test rig is located at Solar's development test facility in San Diego. All work on the first two objectives is complete and has been reported In the Task 8.1 Topical Report now in intemal review. The remaining effort on the third objective involves a continuting long term creep test. This continuing work will be transferred to Subtask 8.7 - Recuperator Materials with finat report coverage in the topical report for Subtask 8.7.

Performance testing of the ATS recuperator core model was accomplished at The Caterpillar Technical Center on the steady state performance rig shown in Figure 1 . Using a 12-inch core sample, this rig measures steady state heat transfer effectiveness and static pressure loss at actual engine operating conditions of temperature and pressure. Testing at a total of 35 ATS gas turbine operating points was completed in the prlor quarter and during this quarter these test restults were anaiyzed and compared with predicted recuperator performance. A topical report covering Subtesk 8.1 will show that measured performance of the ATS recuperator core is in full support of estimaled data used th calculating ATS gas turbine performance in Task 6 . This rig was also used to obtain themal transient characteristics of the core. These results will be a key input to modelling the dynamic response of the recuperated ATS gas turbine.

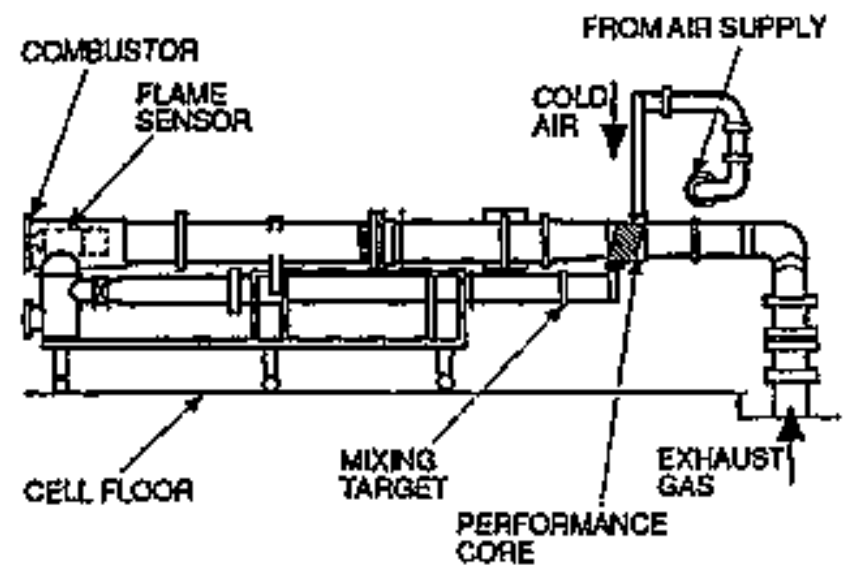

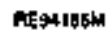

Figure 1.

Steady State Performance Test Rig

The transient test rig is used to obtain pressure drop and themal response data. These parameters are used in the design, analysis and prediction of performance of recuperators. In order to improve the accuracy of the data used in various computer models of performance, it was decided to run an air-side only surface, a

gas-side only surface and a combined air and gas side surface. All three surfaces have been manufactured. The air and gas surfaces were assembled and delivered to Caterpillar. The combined surface will be assembled and delivered shortly. The rig has been extensively calitorated using stanclard heat transfer cores. These cores have been used over the years to ensure validity and integrity of the rig. The most recent tests show excellent agreement, both with and without the thermal attenuator which was added recently to the rig. An uncertainty analysis has also been performed and it reveals an uncertainty exists of about eight percent in heat transfer performance data but only three percent in pressure/friction data. At typical NTUs (Number of Transfor Units, see Glossary), a 12 percent change in heat transfer perfomance data wid cause a one percent change in effecttveness. 


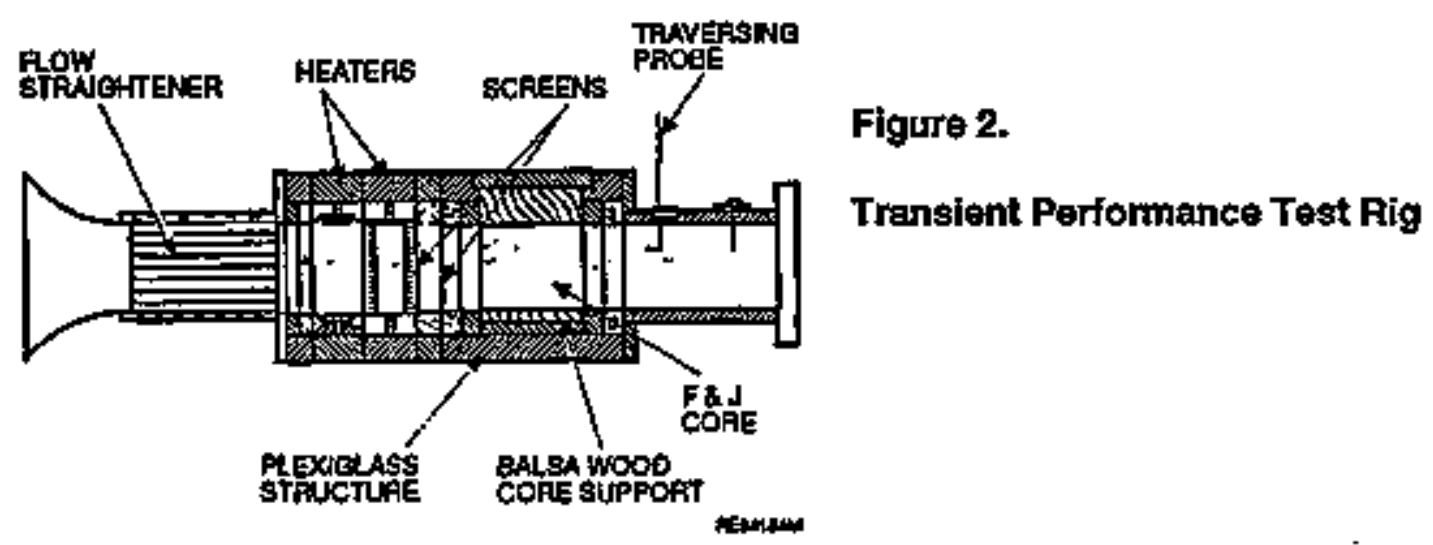

The results of the tests on each core are shown in Tables 1, 2 and 3 (surfaces 90, 91, and 92, respectively). The high capacity surface, which will be used in the recuperator for the ATS program, was tested for botth gas side, air side and combined surfaces (cores 90, 91 and 92, respectively). These empirical data are needed in the design, analysis and prediction of performance of primary surtace recuperators. It is clear there is quite a difference between the air and gas sides, especially at the higher Reymolds numbers. This potentially could result in hlgher accuracy predlctions of pertormance.

Results from the transient rig testing will also be reported in the Subtask 8.1 topical report. The resulting heat transfer stuface characteristic data will also be incorporated into Solar's 2D analytlcal model in order to sharpen the model's abillty to predict recuperator performance.

Creep evaluation, the third objective, is conducted using a flattened tube to simulate a scaled-up cross sectlon of the recuperator primary surface folded profile. The scale-up is necessary in order to provide a test article of sufficient size to attach strain gages. A room temperature pressure test shows that strain measurements are in good agreement with an ANSYS finite element model at pressures below $200 \mathrm{psi}$ - the normal range of operation of ATS recuperators (Figure 3). The test work has advanced into the high temperature creep test stage and has progressed past the point of strain gage saturation. From that point forward, creep strain is being measured by dimensional measurements of the tube itselt.

As of the end of the quarter just past, the flattened tube test rig has operated 1896 hours of testing of a Type 347 stalnless steel specimen plus another 456 hours on a Haynes Alloy 230 . Type 347 is the recuperator sheet alloy used in all primary surface recuperator production to date at Solar and will be used initially in ATS. Haynes 230 is one of several elloys with increased temperature cepability which are candidates for future ATS improvements.

In order to allow timely publication of the Subtask 8.1 topical report dealing primarily with recuperator performance issues, the continuing flattened tube test work wili be moved to Subfask 8.7 which deals with recuperator materials. Thls will have no effect on the distribution of planned labor and costs between these two subtasks.

\subsubsection{Subtask 8.2 - Subscale Catalytic Combustion Rig}

This task was formerty titled "Low Pattern Factor Combustor" and had as Its objectlve the reduction of combustor outlet temperature pattem factor to a level compatible with very high average temperature levels. Revision A003 to the contract added Subtask 8.5, originally titled "Low 
Table 1. Transient Performance Data for Core 90 (Gas-side).

\begin{tabular}{|c|c|c|c|c|c|c|}
\hline Quantly & Run \#1 & Run \#2 & Aun $\#$ & Run \#4 & Run $\forall 5$ & Run $\# 6$ \\
\hline$P_{\text {besomentios }}$ in $-\mathrm{Hg}$ & 29.62 & 29.62 & 29.62 & 29.63 & 30.07 & 29.64 \\
\hline$T_{\infty, \text { anklenst, }},{ }^{0} \mathrm{~F}$ & 72.32 & 72,32 & 72.5 & 72.32 & 72.66 & 72.68 \\
\hline$\Delta P_{\text {colh, atilies, }}$ in $\mathrm{H}_{2} \mathrm{O}$ & 5.36 & 2.145 & 11.62 & 6.02 & 1.36 & 1.69 \\
\hline$P_{\text {tend, antra in }}$ in $\mathrm{H}_{2} \mathrm{O}$ & -1.825 & -0.875 & -3.4 & -0.4 & -0.125 & -4.8 \\
\hline$\Delta \mathrm{P}_{\text {cott, soces, in }}$ in $\mathrm{H}_{2} \mathrm{O}$ & 0.925 & 0.465 & 1.65 & 0.205 & 0.085 & 2.31 \\
\hline$P_{\text {soth, }}$ corre, in in $\mathrm{H}_{2} \mathrm{O}$ & -0.8 & -0.38 & -1.575 & -0.15 & -0.04 & -2.325 \\
\hline 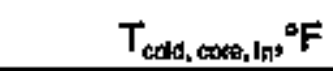 & 71.69 & 71.69 & 72.14 & 71.57 & 72.74 & 72.26 \\
\hline 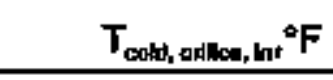 & 72.68 & 73.04 & 72.77 & 73.31 & 73.58 & 72.68 \\
\hline$\Delta \mathrm{P}_{\text {hot orlicer }}$ in $\mathrm{H}_{2} \mathrm{O}$ & 5.41 & 2.15 & 11.76 & 6 & 1.27 & 1.73 \\
\hline$P_{\text {not }}$ OrIICB, in in $\mathrm{H}_{2} \mathrm{O}$ & -1.85 & -0.85 & -3.4 & -0.4 & -0.12 & -4.9 \\
\hline$T_{\text {hol, cort: hit }}{ }^{\circ} \mathrm{F}$ & 92.9 & 92.72 & 92.24 & 93.86 & 94.4 & 92.18 \\
\hline$T_{\text {hol, odlien, },{ }^{,},}{ }^{\circ} \mathrm{F}$ & 87.08 & 86.72 & BB.16 & 85.64 & 83.84 & 88.16 \\
\hline$t_{1}$ anglapea sec & 8.398 & 11.856 & 6.164 & 18.286 & 32.144 & 5.095 \\
\hline
\end{tabular}


Table 2. Translent Performance Data for Core 91 (Air-side).

\begin{tabular}{|c|c|c|c|c|c|c|}
\hline Quantity & Run \#1 & Run \#2 & Aun ${ }^{* 3}$ & Run \#4 & Run \#5 & Run \#6 \\
\hline $\mathbf{P}_{\text {barametors }}[\mathrm{n}-\mathrm{Hg}$ & 29.72 & 29.37 & 29.32 & 29.3 & 29.28 & 29.27 \\
\hline$T_{\text {de enmberth, }}{ }^{9} \mathrm{~F}$ & 72.86 & 71.96 & 72.32 & 72.5 & 70.34 & 70.52 \\
\hline$\Delta P_{\text {cotw, otteran in }}$ in $\mathrm{H}_{4} \mathrm{O}$ & 3.915 & 11,675 & 5.16 & 16.67 & 3.045 & 6.075 \\
\hline 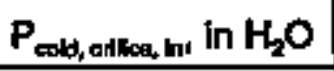 & -0.775 & -1.525 & 3.45 & -7.575 & -12.6 & -21.6 \\
\hline$\Delta \mathrm{P}_{\text {sola, corm in }}$ in $\mathrm{H}_{2} \mathrm{O}$ & 0.67 & 1.21 & 2.575 & 5.22 & 8.38 & 13.88 \\
\hline 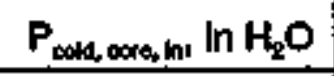 & -0.095 & -0.25 & -0.775 & $-2,165$ & -3.8 & -6.975 \\
\hline$T_{\text {cotde, cone, in }}{ }^{\circ} \mathrm{F}$ & 72.86 & 71.87 & 72.23 & 72.23 & 69.89 & 70.66 \\
\hline$T_{\text {ools, orilke, in }}{ }^{\circ} \mathrm{F}$ & 73.58 & 73.04 & 72.59 & 72.5 & 70.43 & 70.88 \\
\hline$\Delta \mathrm{P}_{\text {het, orithese }}$ in $\mathrm{H}_{2} \mathrm{O}$ & 3.93 & 11.78 & 5.22 & 16.66 & 3.04 & 5.99 \\
\hline $\mathrm{P}_{\text {nol, watces in in }}$ in $\mathrm{H}_{2} \mathrm{O}$ & -0.8 & -1.55 & -3.5 & -7.7 & -12.8 & -21.6 \\
\hline$T_{\text {hol, core, in, }}{ }^{\circ} \mathrm{F}$ & 91.1 & 92.84 & 92.12 & 91.76 & 91.46 & 90.27 \\
\hline$T_{\text {hrot, odthen, inn }}{ }^{\circ} \mathrm{F}$ & 83.84 & 84.74 & 65.82 & 87.44 & 87.08 & 86.9 \\
\hline$t_{1}$ ang gopes sec & 28.4 & 17.4 & 11 & 7.46 & 5.78 & 4.4 \\
\hline
\end{tabular}


Table 3. Transient Performance Data for Core \$92 (combined ait/gas).

\begin{tabular}{|c|c|c|c|c|c|c|}
\hline Quantity & Run \#1 & Run \#2 & Run \#3 & Run \#4 & Run \#5 & Run \#6 \\
\hline$P_{\text {harimelute }}$ in- $\mathrm{Hg}$ & 29.67 & 29.67 & 29.67 & 29.66 & 29.68 & 29.65 \\
\hline 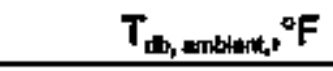 & 73.31 & 73.85 & 72.59 & 72.95 & 72.68 & 72.68 \\
\hline$\Delta \mathrm{P}_{\text {cotal, orillose }}$ in $\mathrm{H}_{2} \mathrm{O}$ & 3.88 & 16.795 & 5.85 & 14.625 & 2.84 & 4.45 \\
\hline$P_{\text {tod, oxsos, in in }} \mathrm{H}_{2} \mathrm{O}$ & -0.37 & -1 & -2.29 & -4.61 & -8.25 & .11 .775 \\
\hline 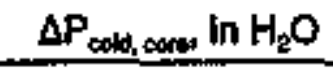 & 0.22 & 0.59 & 1.315 & 2.5 & 4.21 & 5.83 \\
\hline$P_{\text {cold, sone, in in }}$ in $\mathrm{H}_{2} \mathrm{O}$ & -0.09 & -0.32 & -0.85 & -1.9 & -3.6 & -5.35 \\
\hline$T_{\text {cold, corat, } \text { Int }^{\circ}}{ }^{\circ} \mathrm{F}$ & 73.64 & 73.79 & 72.2 & 72.32 & 72.47 & 72.32 \\
\hline$T_{\text {colde, anksa, inn }}{ }^{\circ} F$ & 74,21 & 74.48 & 72.77 & 72.68 & 72.68 & 72.23 \\
\hline$\Delta \mathrm{P}_{\text {hot, arilcar }}$ in $\mathrm{H}_{2} \mathrm{O}$ & 3.96 & 16.92 & 5.94 & 14.71 & 2,86 & 4.46 \\
\hline $\mathrm{P}_{\text {thot, nolles, lng }}$ in $\mathrm{H}_{2} \mathrm{O}$ & -0.35 & -7.05 & -2.3 & -4.65 & -8.3 & -11.8 \\
\hline$T_{\text {trot, sore, min }}{ }^{\circ} \mathrm{F}$ & 92.42 & 91.82 & 91.46 & 90.92 & 91.28 & 90.56 \\
\hline$T_{\text {nol, orfine, min }}{ }^{\circ} \mathbf{F}$ & 62.76 & B5.28 & 86.72 & 86.9 & 87.44 & 87.08 \\
\hline$t$, emplesese sec & 29.8 & 17.5 & 11.16 & 7.73 & 5.81 & 4.88 \\
\hline
\end{tabular}

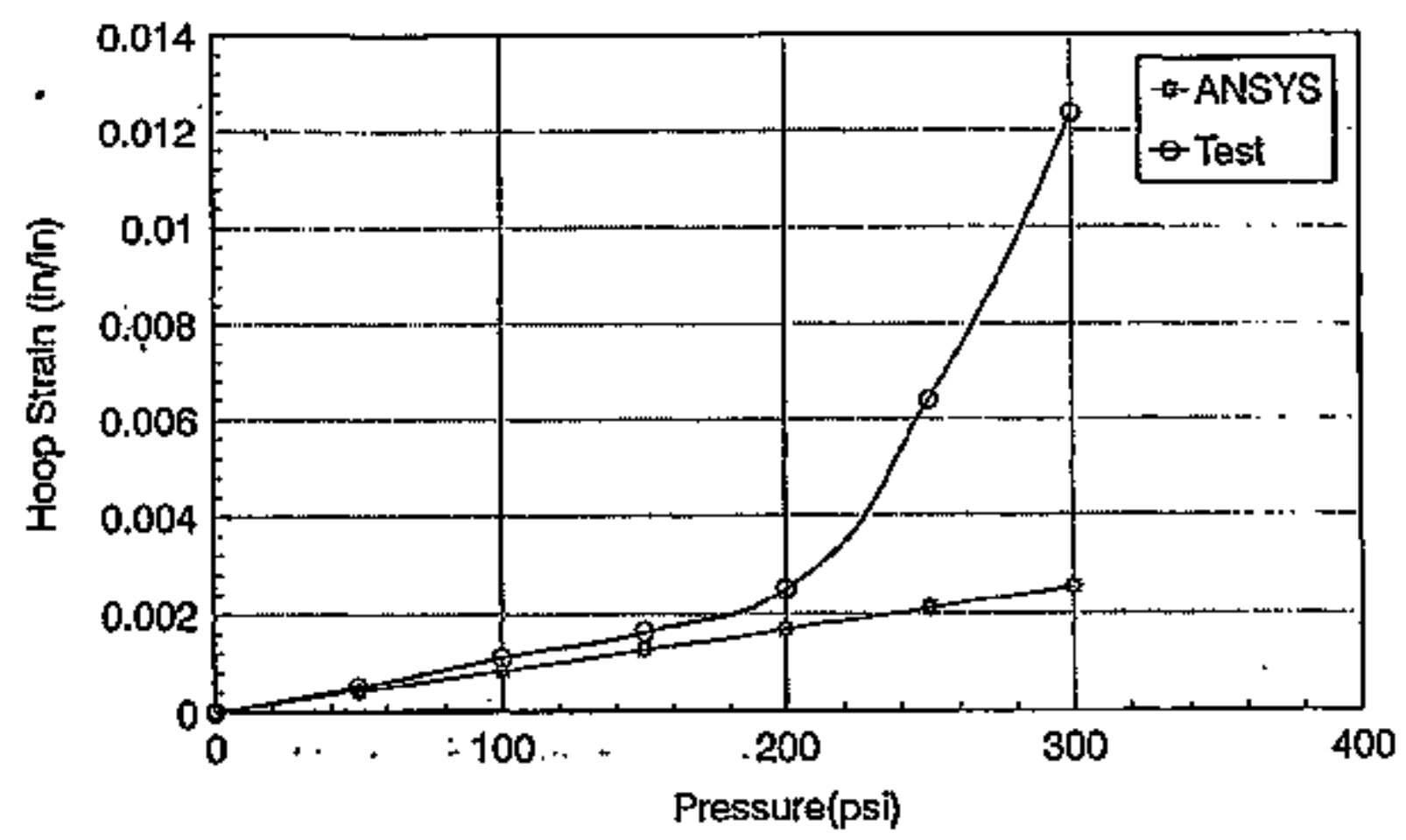

Figure 3. Flattened Tube Tests and FEM Strain Comparison at Room Temperature 
Emissions Combustor." Both subtasks are now addressing the development of very low emsission and low pattern factor catalytic combustion for Solar's ATS. Subtask 8.5 is now tijled "Full Scalo Catalytic Combustion Rig," and will feature a single full-scale ATS combustor can.

At the close of the last reporting period, unsatisfactory performance of the subscale catalytic combustor with the longer ( $10.5 \mathrm{inch}$ ) bed was attributed to an unacceptable catalyst inlet velocity profile.

Measurements of the velocity profile of gases entering the catalyst have been completed for several premixer configurations to improve the profile. A five-hole pitot probe was lraversed directy upstream of the catalyst bed in two radial directions. These tests were completed at ambient conditions (atmospheric pressure and $70^{\circ} \mathrm{F}$ ). Results, included in Figure 4, are plotted as velocity versus position across the catalyst inlet cross-section. On this plat, 2 lnches corresponds to the flow path centerline. The baseline configuration shown as "Position A" has been used in all recent combustion testing. This configuration yielded a +44 percent peak-average variation in the flow fteld. The goal is $a+10$ percent poak-average variation.

Three modifications to the premixer to flatten the catalyst inlet proflle have been tested. Results are shown in Figure 4.

1) The first configuration changes the baseline by replacing the $3-4$ inch premixer diffuser with a constant 3 inch diameter premixer duct from the venturi to the catalyst bed (designated as " 3 inch Diameter Flow Path" in Figure 4).

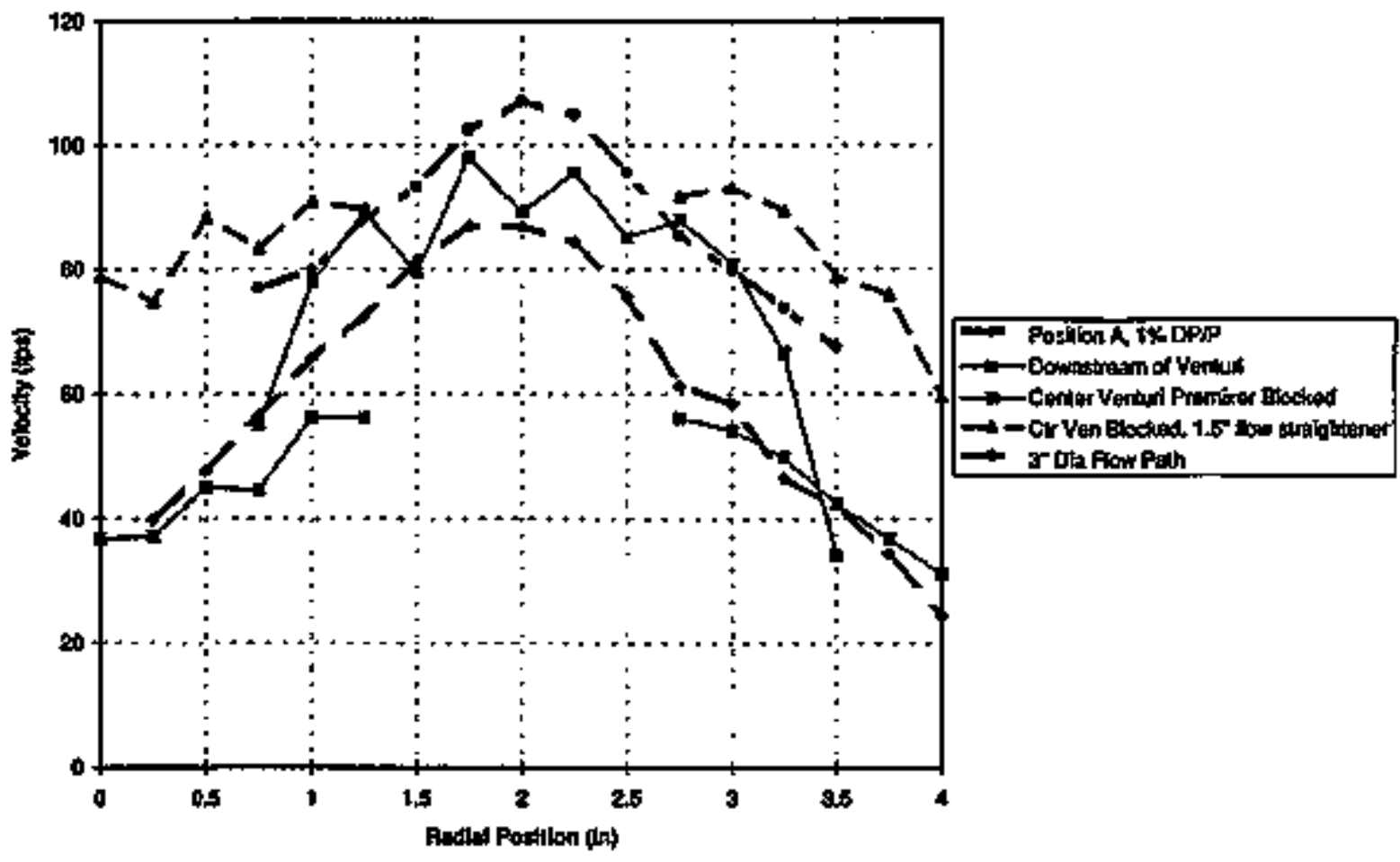

Figure 4. Catalyst Inlet Velocity Profiles 


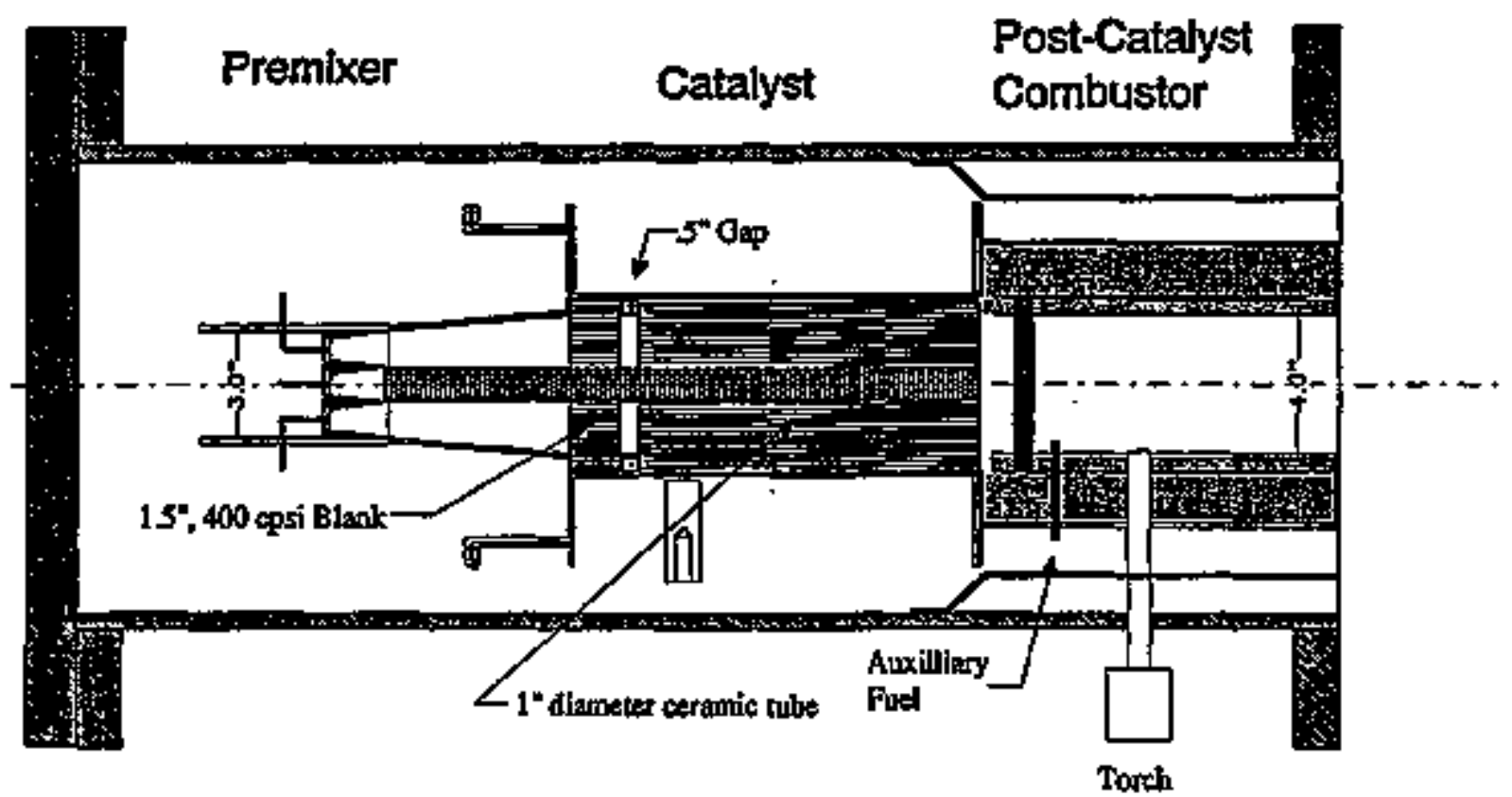

Figure 5. Subscale Catalytic Combustor Test Rig Configured to Flatten Catalyst Inlat Velocty Profile

2) The configuration labelled "Center Venturi Prembxer Blocked" has a one inch diameter rod mounted along the centerline from the venturi outlet to the exit of the catalyst bed. This rod completely blocks the center venturi.

3) The final contiguration is an extension of 2), above, which has been modified by including a 1.5 inch flow straightener upstream of the catalyst bed. This conftguration is illustrated a Figure 5.

The data shown in Figure 4 indicates that all these configurations flattened the profile but the arrangement of Figure 5 provided the flattest profile at +11 percent peak-average. Based on these results, the combustion rig was modified to reflect the changes illustrated In Figure 5. Combustlon testing with thls configurationhas been completed.

This configuration was tested for both fuel profile and combustion performance. This design has provlded the flattest velocity profile entering the catalyst bed at +11 percent peak-to-average. This fuel profile was measured and optinized to $\mathbf{6} \mathbf{6 . 7}$ percent peak-to-peak.

A serles of combustion tests were conducted over a three day period, yielding the best results to date. The combustor was operated for over 2 hours without any auxilliary fuel burning downstream of the catalyst bed with rlg pressure at $120 \mathrm{psig}$. The system operated in a stable manner over a range of irlet lemperalures from $770^{\circ} \mathrm{F}$ to $900^{\circ} \mathrm{F}$ and a variation in furelair ratio from 4 to 3.7 percent (volume). The NOx emissions were consistently below $3 \mathrm{ppmv}$ (corrected to 15 percent $\mathrm{O}_{2}$ ). $\mathrm{CO}$ and HC emissions, however, were as high as $1000 \mathrm{ppmv}$ of CO and $250 \mathrm{ppmv}$ of HC. Some of the "cleaner" data is plotted in Figure 6 . Here $\mathrm{CO}$ is near 100 pprrv and $\mathrm{HC}$ below $60 \mathrm{ppmv}$.

On post-test inspection the bed was found to be in good condition except for a 1 square inch circle where the bed was defomed and some of the material was missing. The cause of this failure was 


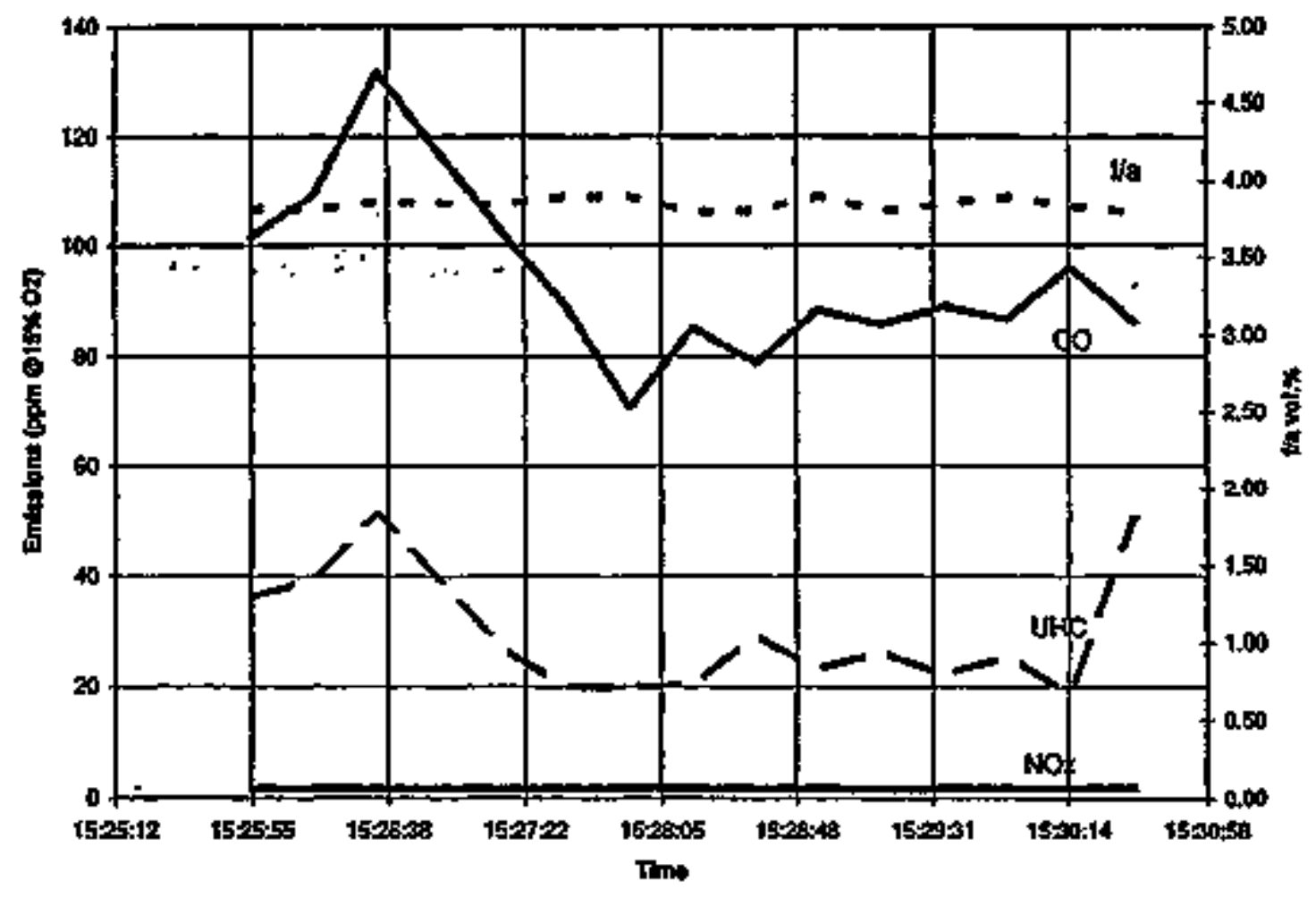

Test $80,4 / 25 / 95 ; 120$ psig, 60 fps, $900^{\circ} \mathrm{F}$

Figure 6. Catalytic Combustor Results

a hot epot - bed temperature exceeding $2500^{\circ} \mathrm{F}$ - that developed during testing at the higher fuelfair ratios. Catalyst supplier Engelhard is completing the analysis of the used bed.

A catalyst bed with the sarne design is being prepared for more testing. The volume of the postcatalyst combustor will be increased by enlarging the flow diameter from 4 inches to 6 inches.

This volume change will increase the residence time from $9 \mathrm{msec}$ to 20 msec. This is expected to improve the bum-out of $\mathrm{CO}$. The optimum $\mathrm{CO}$ burnout will occur at residence times of 35 msec. Modifications to increase the residence time toward this target are being designed. Testing with the 6 inch diameter flow path will be completed during May.

\subsubsection{Subtask 8.3 - Autothermal Fuel Reactor (ATR)}

Autothemal fuei reformation consists in reacting a hydrocarbon fuel such as natural gas (methane) with steam in order to produce a "reformed" fuel with a high hydrogen content - on the order of 70 percent or greater. Since hydrogen bums in leaner mixtures and at lower temperatures than other fuels, this "reformed tuel' will produce inherently lower NOx emissions. In an ATS, a combustor can with a built-in ATR has the potential of very low emissions. In addition, ATRs can be designed for use with a wide varieby of altemate fuels - coal- and biomass-derived gaseous ftels, for example - and can also increase gas turbine efficiency when the steam required for the process is produced with recovered exhaust heat. Solar's ATR project was begun using a tube reactor as shown in Figtre 7 . This rig has been used to establish the basic characteristics of the process and, further, 


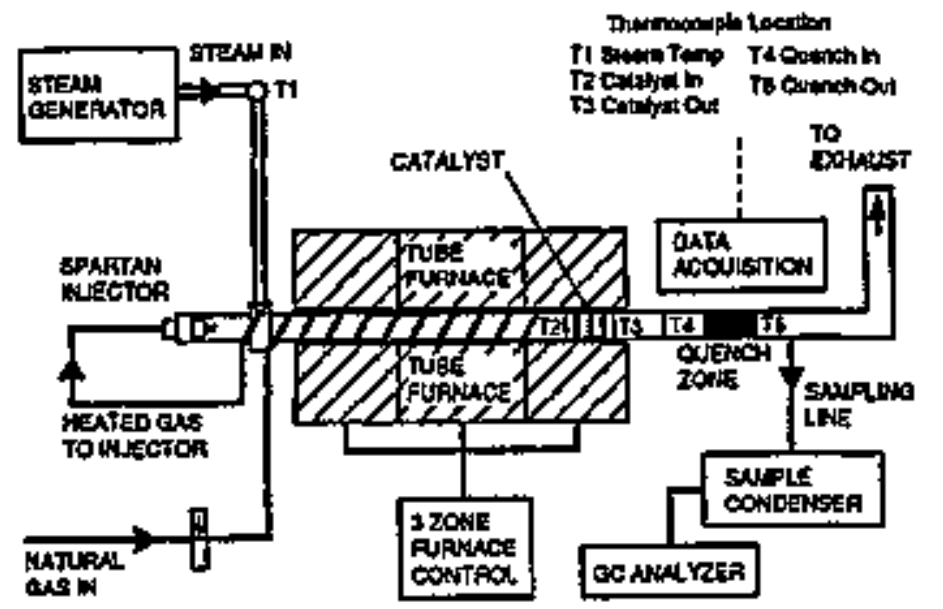

Manition
Figure 7.

Tube Reactor for Fioforming Catalyst Screening Tests

to address several durability issues sutch as catalyst life and the effect of certain acidic compounds $\mathrm{H}_{2} \mathrm{~S}, \mathrm{HCl}$, for example) often found in raw natural gas. These results were reported in the previous quarter. The tube reactor is now being modified in antlicipation of future work on diesel fuel and coal- and blomass-derived fuels.

Fabrication of the modified ATR test rig is nearing completion. Ceramic monolths coated by nickel reforming calalyst with lantharum as a promoter were received from the supplier and rig testing will be resumed.

Tests using the ATR batch-tube reactor on the reformation of liquid (diesel) fuel have confirmed the production of over 60 percent hydrogen in the product stream. The product gas ignition can be achieved without torch assistance at temperatures of approximately $800^{\circ} \mathrm{F}$. The igrition energy of the hydrogen rich gas is much less than that of natural gasu-a major factor in making low temperature catalytic combustion possible.

Next, attempts were made to compare the ignition behavior of reformer product streams using the ATS batch-tube reactor. Temperature readouts monitored by thermocouples are lilustrated in Flgure 8 where a controlled air flow was Introduced downstream of the reformer to bum the product gas. As shown, the product streams with hydrogen above 37 percent were ignited easily without torch assistance with both diesel fuel and matural gas as the feedistock. Under the same conditions natural gas heated through the tube reactor without reforming raised the temperatures only about 100F. This low ignitton energy requirement is one of the benefits for reformation of conventional fuels to produce hydrogen rich gas for combustion in a gas turbine.

The ATR test rig has been reassembled and installed at the existing test facility after modficalion. The testing is designed to evaluate the combustion efficiency, ennission levels, pressure drop, operating range and flame temperature. Stability of combustion of the hydrogen-rich product gas and any tendency toward flashback will also be monitored during the test.

\section{2 .4 Subtask 8.4 - Dual Property Turbine Disc}

The objectlve of this subtask is to provide Solar's ATS with a turbine disc with improved high temperature creep strength in the rim portion while maintaining current levels of low cycle fatigue (LCF) strength/ife at the hub. Improving the high temperature creep strength of the rim portion contributes to gas turbine themnal efficiency by reducing the requirements for cooting air bleed flow. This technology can also be applied to Solar's current and future non-ATS product.

The approech selected by Solar and subcontractor Howmet is to produce the rim element by spraycasting MAR-M-247 alloy and the hub from Udimet 720 powder alloy. Consolidation of both materials will be by hot isostatic pressing (HIPing). HIPing will also be applied to achieve a solid-to. solld bond between the two elements. 

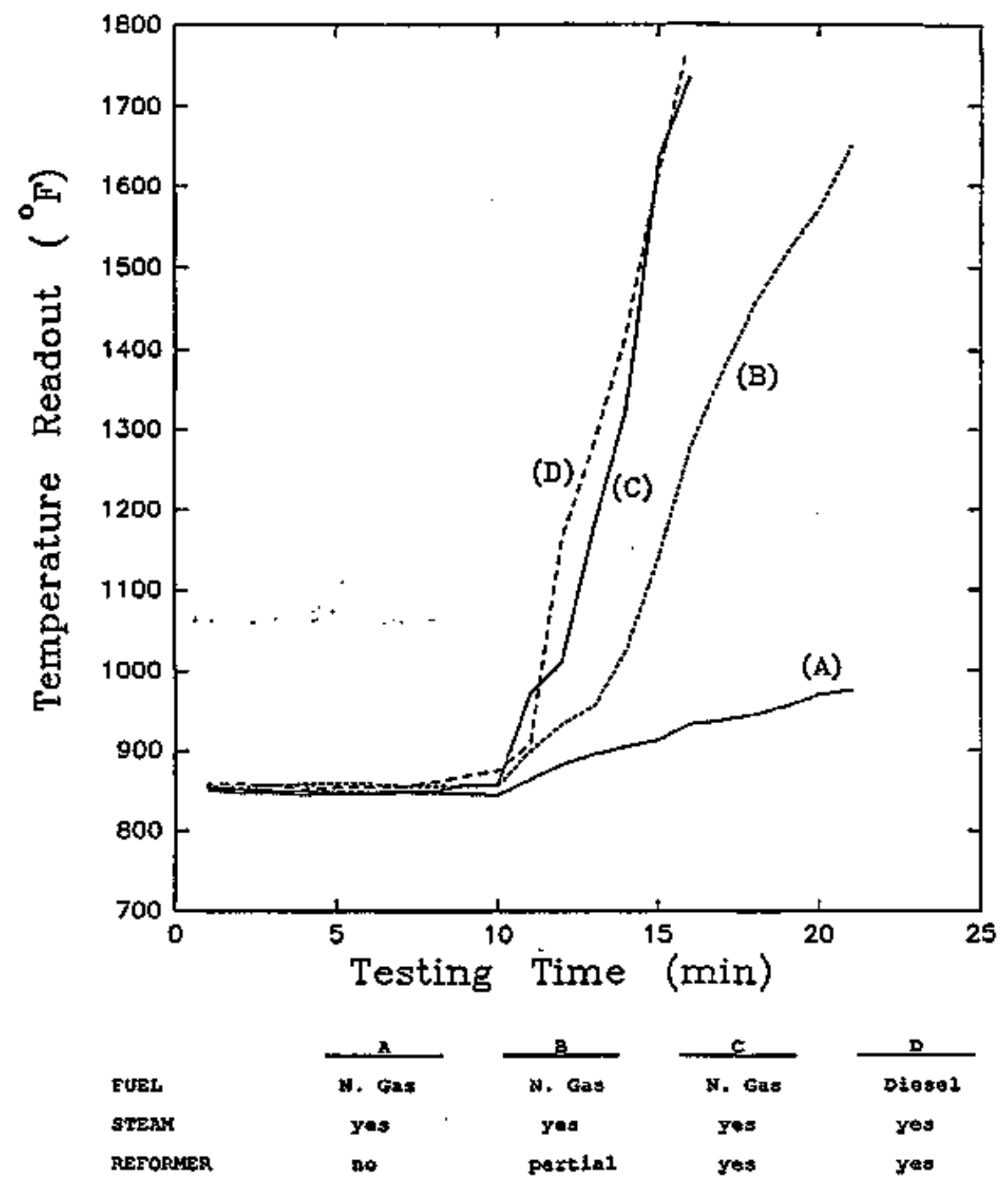

GAS STFEAM COMPOSITION (after hated tube-ratetor): (dxy, voli)

$\begin{array}{lrrrr}\mathrm{H} 2 & 3.36 & 37.11 & 62.55 & 62.14 \\ \mathrm{CH} & 90.65 & 49.26 & 13.78 & 5.64 \\ \mathrm{CO} & 1.43 & 5.15 & 22.21 & 22.82 \\ \mathrm{CO2} & 1.60 & 8.46 & 1.45 & 9.13 \\ \mathrm{C2} & 2.95 & - & - & 0.23\end{array}$

Figure 8. Temperature Readouts Monitored by Thermocouples 
During this quarter, subscale (3- 9 - and 13 -inch diameter) rim elements have been successfulty spray cast, HIPed and heal treated. Microstructure evaluation has been completed and mechanical properties testing is underway. First article Udimet 720 hubs will arrive early in the next quarter and bonding trials will begin.

In addition to the spin-off potential of the dual alloy turbine disc technology into Solar's non-ATs product, successtul spray casting of the rim alloy has identified further spirt-off potential in the manufacture of gas turbine parts. Application of spray casting to ring-shaped gas turbine parts in high temperature alloys can provide one or more of the following:

- Parts which cost less than those made from ing forgings.

- Parts from "unforgeable" alloys

- Parts from alloys providing creep-rupture strength not obtainable in forged alloys.

\subsubsection{Subtask 8.5 - Full-Scale, Single Can Catalytic Combustor Rig}

This subtask was added by Revision A003 to the contract and was originally titled "Low Emissions Combustor." As part of an overall catalytic combustor project along with Subtask 8.2 It Is now defined as catalytic combustor development using a full ATS-scale, single can rig.

The basic destign of this rig was completed in the previous quarter and placed on hold during much of the quarter just past. The hold was put in place to allow for the detail design to accommodate changes indicated by the subscale rig test work of Subtask 8.2. Primarthy these changes relate to obtalning a salisfactory catalyst tintet velocity profile and to providing sufficient post-catalyst volume to enable more complete $\mathrm{CO}$ burn out.

\subsubsection{Subtask 8.6 - Total Plant Controls}

During the quarter covered by this report design specification for the ATS MMil (Man-Machine Interface) was completed. Work continued throughout the quarter on the following long-term elements:

- The Application Programming Interface for the GMS (Graphical Modelling System) graphical user interface.

- Automatic configuration and embedding routines.

- Diagnostic and security routines.

- The Graphical User Interface (GUI).

- ETHERNET and ICN data acquisition comnand modules.

- UNIX-based ancillary processes.

- Dynamic graphics. 


\subsubsection{Sublask 8.7 - Recuperator Materlals}

Thin foll creep testing continued throughout the quarter. All test restits to date (including prior quarters) are listed in Table 4. Results of additional creep testing performed by subcontractor Westmoreland Mechenical Testing and Research, Ins., are listed in Table 5.

The dual alloy portion of the protect was begun this quarter by Initialing a contract with subcontractor Belt Technologles for laser welding of the thin foils of different alloys. Evaluation of formability and other characteristics of these joints will follow.

\section{1,2,8 Subtask 8.8 - Low Cost Combustor Materials (Ceramics)}

During this quarter subcontractor LoTeo fumished flexure bars, erosion plates and coefficient of expansion bars. Procurement of additional material specimens from subcontractors AEA Technologles and International Thermoproducts is also under way. During this process the requirements for test equipment are being defined by Solar.

\subsubsection{Subtask 8.9 Advanced Ceramic Materlal}

The candidate ATS component for demongtration of fabricability in a ceramic composite has been identified as the combustor to stage one nozle transition duct. The earliest candidate was a reverse flow combustor exit duct which has since been eliminated from the ATS design. An interim candidate was an interturbine duct conststing of concentritc walls connected by raclial struts. The combustor duct was selected on the basis that successful execution in ceramics would conserve more cooling air than would a ceramic turbine duct. Material for the combustor duct will be B.F.Goodrich Supertemp's SiC/SiC CFCC. Solar engineers have met with the subcontractor to review the preliminary design of the duct and to determine the level of effort for the finite element analysis and life prediction testing. Total cost for this subtask will not change as a result of these negotiations.

\subsection{PAOGRAH SCHEDULE AND BUDDGET}

\subsection{SCHEDULE}

As of April 30, 1995, Solar's Phase II program is less than one month behind schedule. There are no visible impedinents to completion of the entire Phase II scope of work by May 30,1996 , the close of the period of performance set by Revision M004.

\subsection{BUDGET}

As of April 30, 1995, 21,206 labor hours have been charged to the contract versus 22,448 planned. As of the same date, total program cost (including Solar's cost share) was $\$ 2570 \mathrm{~K}$ versus $\$ 3155 \mathrm{~K}$ planned. In addition to the effect of a labor undernun, further temporary cost underrun represents a billing lag wherein accumulated subcontractor costs have not yet been billed to Solar or passed through to DOE. Solar's Phase II contract is expected to finish very close to the current Labor and Cost Plans (Revision M004). 
Table 4. Thin Foil Creep Test Results

\begin{tabular}{|c|c|c|c|c|c|c|c|c|}
\hline $\begin{array}{l}\text { Tost } \\
\text { No. }\end{array}$ & Direction & Matorjal & $t(n)$ & $\begin{array}{l}\text { Stress } \\
\text { (psi)) }\end{array}$ & Temp(f) & $\begin{array}{l}\text { 5\%Croep } \\
\text { Catcul. } \\
\text { HRS }\end{array}$ & $\begin{array}{c}5 \% \text { creep } \\
\text { Actual } \\
\text { HRS }\end{array}$ & $\begin{array}{c}\text { Rupture } \\
\text { Actual } \\
\text { HRS }\end{array}$ \\
\hline$\# 3$ & Unkwn & SS 347 & 0.0032 & 17000 & 1300 & 127 & 166 & 195 \\
\hline$\# 4$ & Long & \$S 347 & 0.0032 & 17000 & 1300 & 127 & 165 & 194 \\
\hline$\# 6$ & Long & Ss 347 & 0.0082 & 17000 & 1200 & 2715 & $k$ & 1500 \\
\hline$\# 7$ & Trans & SS 347 & 0.0032 & 17000 & 1300 & 127 & 224 & $25 t$ \\
\hline$\# B$ & Unkwn & SS 347 & 0.0032 & 17000 & 1200 & 2715 & 2391 & 2630 \\
\hline$\# 9$ & Trans & SS 347 & 0.0032 & 17000 & 1200 & 2715 & $f$ & 1203 \\
\hline$\# 12$ & Long & SS 347 & 0.0032 & 17000 & 1250 & 560 & 1 & 842 \\
\hline$\# 13$ & Trans & SS 347 & 0.0082 & 17000 & 1250 & 560 & j & 842 \\
\hline$\# 14$ & Long & SS 347 & 0.0032 & 17000 & 1250 & 560 & 1 & 460 \\
\hline$\# 16$ & Trans & SS 347 & 0.0082 & 14000 & 1300 & 277 & $\mathrm{~b}$ & 220 \\
\hline$\# 17$ & Long & SS 347 & 0.003 & 17000 & 1250 & 560 & $\mathbf{a}$ & 725 \\
\hline$\# 18$ & Trans & SS 347 & 0.003 & 17000 & 1250 & 560 & 960 & 1025 \\
\hline$\# 19$ & Unkwn & Ss 347 & 0.003 & 14000 & 1300 & 277 & b & 490 \\
\hline$\$ 20$ & Trans & S\$ 347 & 0.003 & 14000 & 1300 & 277 & 700 & 1020 \\
\hline$\# 21$ & Unkwn & SS 347 & 0.0025 & 11000 & 1300 & 649 & 1331 & 2080 \\
\hline$\# 22$ & Unkwn & Ss 347 & 0.0025 & 11000 & 1300 & 649 & $\theta$ & 3773 \\
\hline$\# 23$ & Unkwn & \$S 347 & 0.0025 & 9000 & 1300 & 1170 & 2556 & $4400 \mathrm{~g}$ \\
\hline$\# 24$ & Unkwn & SS 347 & 0.0032 & 12000 & 1250 & 2154 & 2687 & 3158 \\
\hline$\# 26$ & Trans & Inconel 625 & 0.0037 & 30000 & 1330 & $1344 c$ & 109 & 436 \\
\hline$\# 26$ & Long & Incoriel 625 & 0.003 & 11000 & 1440 & $3360 \mathrm{c}$ & 739 & d \\
\hline$\# 27$ & Trans & Inconel 625 & 0.003 & 11000 & 1440 & $3360 \mathrm{c}$ & 637 & $1077 \mathrm{~g}$ \\
\hline
\end{tabular}


Table 4. Thin Foil Creep Test Results (Continued)

\begin{tabular}{|c|c|c|c|c|c|c|c|c|}
\hline $\begin{array}{l}\text { Tost } \\
\text { Mo. }\end{array}$ & Direction & Materlal & $t(i n)$ & $\begin{array}{l}\text { Stress } \\
\text { (posl) }\end{array}$ & Tomp(F) & $\begin{array}{c}\text { 5\%croesp } \\
\text { Calcul. } \\
\text { HRS }\end{array}$ & $\begin{array}{c}5 \% \text { Croep } \\
\text { Actual } \\
\text { HRS }\end{array}$ & $\begin{array}{c}\text { Hupture } \\
\text { Actual } \\
\text { HRS }\end{array}$ \\
\hline$\# 28$ & Trans & Inconel 625 & 0.003 & 8000 & 1480 & $4589 \mathrm{c}$ & 442 & $696 \mathrm{~g}$ \\
\hline$\# 29$ & Long & Inconel 625 & 0.003 & 8000 & 1480 & 45690 & 409 & $685 \mathrm{~g}$ \\
\hline$\# 30$ & TBD & SS 347 & 0.0035 & 7000 & 1350 & 2065 & 907 & $1527 \mathrm{~g}$ \\
\hline$\# 31$ & Long & Inconel 625 & 0.0055 & 20000 & 1350 & 700 & 3580 & n \\
\hline$\# 32$ & Trans & Inconel 625 & 0.0035 & 20000 & 1350 & 700 & 3507 & $n$ \\
\hline$\# 33$ & Long & Inconel 625 & 0.0035 & 30000 & 1330 & $1344 c$ & 352 & $750 \mathrm{~m}$ \\
\hline$\# 34$ & Unkwn & Inconel 625 & 0.0035 & 15000 & 1350 & 2663 & $n$ & \\
\hline$\# 35$ & Unkwn & Inconel 625 & 0.0035 & 30000 & 1250 & 1099 & $n$ & \\
\hline $\begin{array}{c}\# 36 \\
340 \cdot \mathrm{L}\end{array}$ & Long & Inconel 625 & 0.0035 & 30000 & 1330 & $\cdots$ & 274 & $670 \mathrm{~m}$ \\
\hline $\begin{array}{l}\# 37 \\
357-T\end{array}$ & Trano & Inconel 625 & 0.0035 & 30000 & 1275 & $\ldots$ & $655 q$ & $q$ \\
\hline $\begin{array}{c}\$ 38 \\
355-T\end{array}$ & Trans & Inconel 625 & 0.0035 & 30000 & 1350 & $\cdots$ & 109 & $p$ \\
\hline $\begin{array}{c}\text { \#39 } \\
334-1\end{array}$ & Long & Inconel 625 & 0.0035 & 25000 & 1350 & -.- & 202 & p \\
\hline $\begin{array}{c}\$ 40 \\
353-T\end{array}$ & Trans & Inconel 625 & 0.0035 & 22000 & 1480 & $\ldots$ & 7.8 & 23.1 \\
\hline
\end{tabular}

a-fuptured at $2.5 \%$ creep.

b-fluphured al 3.5\% croop.

cTha dale is for 0,008 inch foll,

4-Test stopped at 19\% crep.

-fiuplured at 4,4\% creep.

FRupivied al $0.8 \%$ creap.

4-Test stopped at $10 \%$ creep.

h-fiuplured at $3.1 \%$ creep.

IFfupluted al $3.8 \%$ creep.

Fiptured al 2.5\% oreep.

c-Aluptured at $1.55 \%$ oreep.

LAuptured at $0.87 \%$ araeg.

on- fest skopped at 9.5\% crep

n - Test al' nunning

p - Test slopped al $5 \%$ creep

q - Test stopped at $1 \%$ cresp 
Table 5. Thin Foil Creep Testing Summary

\begin{tabular}{|c|c|c|c|c|c|}
\hline $\begin{array}{l}\text { Speclmen } \\
\text { Number }\end{array}$ & Materlal & $\begin{array}{l}\text { Test } \\
\text { stress } \\
\text { (Ksi) }\end{array}$ & $\begin{array}{c}\text { Test Temp. } \\
\left({ }^{\circ} \mathrm{F}\right)\end{array}$ & $\begin{array}{c}5 \% \text { Creep } \\
\text { (thours) }\end{array}$ & $\begin{array}{c}\text { Rupture } \\
\text { Time } \\
\text { (hours) }\end{array}$ \\
\hline $7-347$ & Type 347 SS & 17 & 1225 & $670^{(18)}$ & $\Leftrightarrow$ \\
\hline $2-347$ & 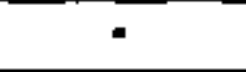 & 12 & 1300 & $670^{(0)}$ & is \\
\hline $340 \cdot \mathrm{L}$ & Inconel 625 & 30 & 1300 & 275 & $670^{\circ}$ \\
\hline 357-T & ‘ & 30 & 1275 & $670^{\circ}$ & 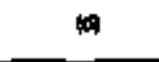 \\
\hline $355 . T$ & * & so & 1950 & 109.5 & $\leftrightarrow$ \\
\hline 334-L & * & 25 & 1950 & 201.2 & in \\
\hline 356-T & - & 22 & 1480 & 6.6 & 201 \\
\hline 394-T & $\mathrm{N}-155$ & 18 & 1950 & $1150.0 \mathrm{n}$ & 13 \\
\hline $251 \cdot \mathrm{L}$ & Hast-X & 25 & 1350 & 32.6 & $\theta$ \\
\hline $171-L$ & RA-85H & 15 & 1350 & 3.2 & 3.3 \\
\hline $3+7-T$ & Incoloy 600 & 17 & 1950 & 2.9 & (a) \\
\hline 214-L & Incoloy 825 & 17 & 1350 & 86.1 & 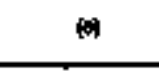 \\
\hline $113-T$ & Incoloy $800 \mathrm{H}$ & 17 & 1350 & 3.1 & $\omega$ \\
\hline $14-\mathrm{L}$ & Haynes 230 & so & 1350 & 40.9 & (1) \\
\hline $52 \cdot 1$ & RA 353 & 20 & 1350 & 87.7 & (1) \\
\hline 154-T & HR 120 & 22 & 1350 & 1.23 & (1) \\
\hline -..--..- & $153 \mathrm{MA}$ & \multicolumn{2}{|c|}{$\begin{array}{c}\text { to be determined after } \\
\text { elevated temp. tensile } \\
\text { tests }\end{array}$} & & \\
\hline
\end{tabular}

(9) lest stopped, total creep .710\%

pit test stopped, total creep $1.28 \%$

- test stopped, total creep $9.3 \%$

(est siopped, total creep 1.03\%

1) test stopped, total creep $5.0 \%$

v test stopped, total creep $2.50 \%$ 
In addition to the charges to the contract, an additional 9249 labor hours have been charged to an intermally funded project directly related to ATS. This represents cost sharing of approximately $\$ 833,000$ in addition to that provided for in the contract.

\subsection{FUTURE INYESTIGATIONS}

During the next quarter work on all contracted Task 8 projects will contlnue as planned. The topical report for the now completed Subtask 8.1 wilt be submitted. Subtask 8.3 - Autothemal Fut Feformer will be completed and a toplcal report prepared. Subtask 8.2 - Subscale Catakytic Combustor Pig will complete its input to the design of the Full-Scale Rig (Subtask 8.7) and work will transition over to that subtask. Economic evaluation of the coal conversion defined in Task 4 will be under way. 


\section{APPENDIX 1}

\section{GLOSSARY}

ACE

ATS

ATS50

ATS60

BASELOAD

BZP

CFATS

CFCC

CHORD

$\operatorname{cseT}$

EDX
Advanced Component Efficlency. A Solar-funded mult-disciplinary, advanced techrology program. It currently includes programs on compressors, turbines, cooling. and ducting.

Advanced Iurbine System. A gas turbine-based energy conversion system as defired To the U. S. Congress by the U. S. Department of Energy (DOE). An ATS is distinguished from current gas turbines by makkedly increased thermal efficiency, reliability, availability and maintainability and by clecreased exhaust emissions and cost of power produced.

Solar's designation for an ATS designed to meet the contract goal of $\mathbf{5 0}$ percent thermal efficiency.

Solar's designation for an ATS designed to meet a "stretch" goal of 60 percent thermal efficiency.

Typically describes a specific number of operating hours the power generation system is operating. In this case it represents (on average) 6500 hours.

Barium Zrconium Phosphate. A farrily of materials whose composition can be tailored to result in low, or zero, coelficient of thermal expansion. It is resistant to themal shock, and is stabie to $1200^{\circ} \mathrm{C}$.

Coal-Ered Advanced Iurbine System. An advanced turbine system modified to operate on coal or coal derived fuel.

Continuous Eiber-Reinforced Ceramis Composite. A high temperature composite material which consists of a ceramic matrix reinforced with fabric, tape, or rows of a high modulus fiber. CFCC's are typically not as ftaw sensitive as monolithic ceramics, and can be fabricated into large parts such as combustion chambers.

The axial length of an airfoil measured along a line drawn tangent to the leading- and trailing-edge radit. Chord is the characteristic dimension used in scaling of airfoils.

Cetamic Stationary Gas Iuthine. A DOE-tunded program contracted to Solar Turbines lncorporated. The program goal is to demonsfrate improved perforrasnce of a production gas turbine by retrolitting key components with ceramic counterparts for a 4000 -hour field test.

Electron Diffraction Xray. 
EFFECTIVENESS

EFFICIENCY, COMPRESSOR

EFFICIENCY, THERMAL

EFFICIENCY, TURBINE

FGM

GAS PRODUCER

GPT

GFATS

GP

HCF
( $e_{\mathfrak{h}}$ for recuperator, $e_{1}$ for intercooler). A characteristic of a heat exchanger the ratio of the amount of heat transferred to the total heat available in the hot fluid between its entry temperature and the entry temperature of the cold filuid.

(n). Ralio of the work imparted to the air flow to the total work input. Unless otherwise specified, "adliabattc" efficiency (subscript. - ad) is Implied, i.e., flow conditions at both inlet and outet are in tems of absolute, or total, pressure and temperature. "Polytropic" efficiency (subscript. - p) is the theoretical efficiency of a very large number of identical kow pressure-ratio stages and essentally normalizes pressure ratio for comparison of differing compressors.

$\left(n_{1 s}\right)$. Also termed cycle efifieiency. The ratio of energy input to energy output from a gas turbine. Unless specifically designated otherwise, thermal eficiency of an ATS will be defined on the basis of net power outpul from the turbine shaft.

(n). Ratio of the work produced by a turbine to the work it extracts from the gas flow. When applied to a GP turbine, totsl-to-total efficiency is implied, this definition being based on total or absolute infet and exit conditions. When applied to a power turbine, total-to-static efficiency is implied, thus accounting for static pressure recovery as a result of kinetic energy conversion in the exhaust diffuser.

Eunctionally Graded Material. A multi-layer material or coating system with each layer graded to provide different properties at the surface of the component relative to the core or substrate. An illustrative example woutd be a turbine tip-shroud with a top coating tailored for abradability, an intermediate layer designed for oxidation resistance, and a substrate tailored for high strength.

(Abbr. GP) An element, or module, of a gas turbine which is required to provide a hot gas stream capable of propelling a power output turbine or other energy corversion device. As a minimum it consists of a compressor, a combustor, a turbine and associated shafting. Each of these components, in tum, may be of any of several types and may consist of one or more stages.

Gas Eroducer Iurbine. May include HP and LP turbines.

Gas-Fired Advanced Iurbins System. An advanced turbine system which uses naturai gas for fuel.

SEe GAS PRODUCER.

High Cycle Eatigue. High cycle fatigue is characterized as the fatigue mechanism where vibratory loads are supertmposed onto a steady state loscing condition. The typical example is turbine blade under aero excitation. The turtine blade exhibits a significant steady state stress level due to the centrifugal load, where vibratory stresses are induced by high frequency pressure perturbations in the gas stream. Visratory stress levels are typically 
HIP

HP

INTERCOOLER

1.0.U.

IPP

LAC

LCF

LP within the elastic range of the materlals. Failures typlcally occur due to excitation at the component's natural frequency, setting up a resonant condition. This falure mode is associated with large numbers (1005 - 10e7) of Jow stress amplitude cycles.

Hot Isostatic Pressing. A process for simultaneously heating a component. or powder metallurgy compact while subjecting it to isostatic pressure using an inert gas afmosphere. The temperature and pressure area are high enough to produce densification of the materials.

High Eressure. This prefix is used to designate an individual section of a series palr of aerodynamic components operating in the high pressure regime of the two. HPC designates the high pressure compressor and HPT designates the high pressure turbine of an HP, or high pressure, spool.

A heat exchanger placed between stages of compression in a gas tumine in order to remove heat from the compression air thereby reducing the temperature of atr going to and through the succeeding stage(s).

Irwestor Qwned Utifity. There are approximately 260 investor owned utilities in the United States. They are differentiated by the fact that they are owned through a stock ownership plan and are usually traded on the open market. they are more tightly regulated in their service area by regulatory bodies gke pubtic utility commissions than the Municipal utilities or the cooperative utilitles.

Independent Eower Producer. A non-regulated producer of electric energy. Currently the majority of these IPPs are larger power generation stations much like the Central Power Station that is owned by the Investor Owned Utilities.

Levelized Annual Cost. The name of the financial model used by the utilities to determine the cost of the capital equipment of the usable life of the equipment. Takes into consideration presert worth arithmetic. Sometimes interchanged with book value analysis/life cycle analysis.

Low Cycle_Faligue. The fatigue mechanism typically essociated with large thermal or mechanical loading. The cycles are typically a transient loading condition, such as start-up and shut-down of an engine. Low cycle fatigue is characterized by allowable pseudo elastic strain range for a material whereby a fatigue crack will develop after a specified number of cycles. typically LCF is considered cyclic loading of the base load leading to plastio deformation. Cycles are on the order of less than 10,000 to 15,000 cycles.

Low Rressure. This prefix is used to designate the individual of a serjes pair of aerodynamic components operating in the lower pressure regime of the two. LPC destgnates the low pressure compressor and LPT designates the low presstre turbine of an LP, or low pressure, spool. 
A designation for an overlay coating applied to superalloy turbine components for increased oxidation and corrosion resistance. "MerAlY" is derived from the elernental constituents of the coating i.e., $\mathrm{Cr} \approx$ Chromium, Al e Alurninum, $Y=$ Yttrium $M=N i \mathrm{Fe}$ or $\mathrm{Co}$ (depending on substrate).

NEPA

National Environmental Policy Act.

NTU

Number of Iransfer Units, a non-dirnensional measure of the theat transfer size" of a heat exchanger. It is defined as:

$$
\mathrm{NTU}=(\mathrm{A}) *(\mathrm{Jav}) / \mathrm{Cmin} \text {, }
$$

where:

$A$ is the heat transfer area (sqft)

Uav is the thermal conductance of the heat exchanger material (Btu/sec- ${ }^{\circ} \mathrm{F} / \mathrm{sqft}$ )

Cmin is the capacity rate (mCp tor the fluid having the smallest capacity rate $(\mathrm{Btu} /(\mathrm{sec} \cdot \mathrm{F}) \mathrm{F})$

PATTERN FACTOR (Abbr. PF). A parameter definting the range of temperatures extant in the exit gas flow from a gas turbine combustor.

$$
P F=\frac{T_{\text {MaX EX }}-T_{\text {AVG EX }}}{T_{\text {AVE EX }}-T_{\text {AVB ALET }}}
$$

All temperatures are absolute.

PF

PITCH

POWER TUABINE

PR

PRIS

\section{See PATTERN FACTOR.}

The circumierential distance between two adjacent aifoils in an axial turbomachinery annulus. It is equal to 2 times pi times the radius from the annulus centerline to the subject airfoll divided by the number of airfoils in the annulus.

(Abbr. PT). A turbine stage in a gas turbine whose work output is used solely to drive the load with none being used by the compressor. In a 2-shalt gas turbline, the power turbine is fixed to a separate shaft from that of the GP turbine. It is nomnally -- but not required to be -- the last, or lowest pressure, turbine stage.

Pressure Batio. For a compressor or compressor stage, the ratio of outlet to inlet total pressure. For a turbine or turbine stage, the ratio of inlet to outlet total pressure.

Particle Rejection Impact Separator. A devlce locateo between the primary and secondary zones of a rich-lean coal fired combustor which removes particulates from the gas stream. 
PAOFILE

PSR

PT

RECUPERATOR

SHROUDED

SPOOL

SA

STAGE WORK FACTOR

STALL

STANDBY
The distribution of gas temperature within a single radial plane of $\mathrm{a}$ gas turbine combustor exit or other downstream annulus. The temperature profile represents the environment experienced by a turbine blade as it rotates through a temperature pattem thus averaging out circumferential variations. A "Profile Factor" can be defined using the Pattern Factor equation but confining the temperature data to a single racial plane.

Primary Surface Becuperator. Solar's proprietary design in which all heat exchange surfaces are "primary." i.e., transferring heat in their transverse direction. (A "secondary" surface, such as a fin, transfers heat in a lateral direction).

\section{SeE POWER TUABINE.}

A heat exchanger placed in the exhaust gas stream of a gas turbine in order to extract heat from the exhaust gases and retum it to the cycle by heating the combustor inlet atr. The tem "recuperator" designates a static device as opposed to a "regenerator" which is a periodic device.

A type of turbine blade design. A "shrouded" turbjine features a short circumferential shroud segment attached to each blade tip. Together, these segments make up a futh circular, rotating shroud. The outside surface of this shroud normatly carries one or more circumferential seal elements. Conversely, a "non-shrouded" turbine is characterized by open blade tips rotating in close proximity to a stationary shroud.

The compression and expansion element of a gas producer, consisting of a compressor, a turbine and assoctated shafting. The turbine is deslgned so as to provide the amount of work required for the compression process plus any mechanical losses. A gas producer includes one or more spools and will be designated as 1-spool, 2-spool, etc.

Stress Bupture. Stress nupture is the failure mechanism where gross rupture occurs due to time dependent deformation caused by steady stress at elevated temperstures. The mecharism at intermediate stages of deformation is called creep and is measured in terms of plastic strain. Stress rupture is usually associated with the Larson-Milter Parameter (LMP) which correlates the relationship between service life in hours and service temperature at a constant stress level. For a given material, Larson-Miller Pararneter curves are developed which depict the LMP as a function of steady stress level.

The ratio of work actually performed by a flow of cooling alr within a turbine stage, to that posslble if the flow were added to the hot gas stream.

A concition arising th one or more stages of an axial compressor in which the design pressure-velocity-rotational speed relationship is disrupted such that separation of the alr flow from the blade contour occurs.

Use as a descriptor of a power generation station or unit that is only drawn upon when there is a demand. It currently is thought of as an emergency 
back-up unit in case the primary system falls, or when the primary unit cannot met the load demand. Sometimes called an "on-demand" system.

SURGE

TBC

T\&D

TRIT

TSSC

ZWEIFEL COEFFICIENT
The condition occutring when a compressor is operated below its minimum stable sir flow rate for a given rotational speed. Surge is characterized by oyclic backflow of air in the flowpath accompanied by violent pressure fluctuations. During surge all stages of the compressor will be in a stall condition.

Thermal Barrier Coating. A thermally insulating ceramic coating $\left(\mathrm{ZrO}_{2}\right)$ applied to superalloy combustor and airfoll components. The Insulative properties of the coating allow increased turbine inlet temperatures while maintaining acceptable metal substrate temperatures.

Iransmission and Distribution. The system used to get the power (or fuel) from the point of origin to the consumer.

Tutbine Botor Inlet Iemperature. The average gas temperature entering the rotor annulus of the first turbine stage in a gas turbine. It is less than the average combustor exit temperature due to the mixing of spent cooling alr flow from tupstream sources, primarily the fist stage nozzle vanes.

Iwo-Stage Slagging Combustor.

A measure of turbine blade loading based on pitch/chord ratio and gas turning angle as independent variables. 